Research article

\title{
Nitrogen level affects growth and reactive oxygen scavenging of fenugreek irrigated with wastewater
}

\author{
Saima Kausar $^{1 *}$, Shahla Faizan ${ }^{2}$ and Irfana Haneef ${ }^{2}$ \\ ${ }^{1}$ Department of Botany, Jhunjhunwala Degree College, Faizabad, Uttar Pradesh, India \\ ${ }^{2}$ Environmental Physiology Laboratory, Department of Botany, Aligarh Muslim University, Aligarh, India \\ *Corresponding Author: kausar.saima25@gmail.com \\ [Accepted: 23 May 2017]
}

\begin{abstract}
Today, due to the constraint in availability of the freshwater for irrigation, wastewater is being used for irrigation of agriculture fields. Wastewater contain plant nutrients that favour crop growth but leave a burden of heavy metals which can enter the food chain and is a cause of great concern. This research work aimed at evaluating the potential utilization of wastewater as an alternative source of water and nitrogen $(\mathrm{N})$ for fenugreek. For this purpose, a pot experiment was conducted with wastewater and four doses of nitrogen $\left(0,20,40\right.$ and $\left.60 \mathrm{~kg}^{-\mathrm{ha}^{-1}}\right)$ to observe a comparative effect on growth and biochemical characteristics using fenugreek as the test crop. Wastewater and soil used in the experiment were analyzed for their physicochemical properties. Results indicate that wastewater was richer in essential plant nutrients but contained some heavy metals in amounts well below the permissible limits for its use as irrigation water. Use of wastewater with $20 \mathrm{~kg} . \mathrm{N} \cdot \mathrm{ha}^{-1}$ improved growth, proline and antioxidant enzymes of the plant as compared to application of groundwater with no fertilizer. Lipid peroxidation increased with wastewater but decreased with the increasing nitrogen doses, so the best combination $\left(\mathrm{WW} \times \mathrm{N}_{20}\right)$ has negative impact on this parameter. These results concluded that wastewater can efficiently substitute groundwater and also works as a nutrient source whereas application of nitrogen could provide protection against the oxidative stress by increasing the antioxidant protective system.
\end{abstract}

Keywords: Trigonella foenum-graecum - Proline - Lipid peroxidation - Catalase - Peroxidase Superoxide dismutase.

[Cite as: Kausar S, Faizan S \& Haneef I (2017) Nitrogen level affects growth and reactive oxygen scavenging of fenugreek irrigated with wastewater. Tropical Plant Research 4(2): 210-224]

\section{INTRODUCTION}

In many parts of the world freshwater resources is scarce, and there is with gradual destruction and increased pollution of fresh water resources, requiring alternatives to supply water for agriculture need to be considered (Yoshida \& Ishii 1993). One solution to insufficient water supplies is water reuse. Sewage water for irrigation is a way to dispose of sewage; provide the reliability of large volumes of water for irrigation; to reduce discharge into potable water bodies; serve as an alternative source to chemical fertilizers, provide organic matter; improve soil infiltration capacity, permeability, cation and anion exchange capacities, water holding capacity and texture (Schneider \& Erickson 1972, FAO 1992, Avemelech 1993, Brady \& Weil 1999, Van der Hoek et al. 2002). However, there is a concern about contamination and bioaccumulation in plants of potentially toxic elements such as chromium $(\mathrm{Cr})$, lead $(\mathrm{Pb})$, nickel $(\mathrm{Ni})$, cadmium $(\mathrm{Cd})$, copper $(\mathrm{Cu})$ and zinc $(\mathrm{Zn})$ from domestic and industrial sources (Chen \& Chia 2002, Kiziloglu et al. 2007).

In urban areas, especially in developing countries, raw wastewater for irrigation is used to grow vegetables for nearby urban markets (Lucho-Constantino et al. 2005). If the wastewater is used after proper dilution for irrigation hazards of heavy metals can be minimized (Pathak et al. 1999). The water used in the proposed research work has already been diluted from the source (Tak et al. 2012, Akhtar et al. 2012, Iqbal et al. 2012, 2017, Chalkoo et al. 2014, Sahay et al. 2015) and the contents of all the heavy metals except Ni were well within the permissible limits of Awasthi (2000) (Table 1). The presence of pathogenic microorganisms in wastewater poses an additional health-hazard. In order to avoid this problem, side-on-soil-surface watering was 
used with watering can and practiced in pots to avoid direct contact with crop foliage. However, two weeks before the harvest, this technique was replaced by direct watering on the foliage (Cisse 1997, Akponikpe et al. 2011). Wastewater provides variable nutrients and improves attributes of the plant compared to fresh water, but the nutrient concentrations are not sufficient to fulfill requirements of the crop. External inputs need should be guided by the efficiency of their use, as the use of fertilizers beyond limits, in addition to being uneconomical, is potentially harmful to the environment by leaching through the soil beyond the root zone, eventually reaching ground water, or through surface runoff be deposited into nearby water bodies and cause eutrophication.

Table 1. Physicochemical characteristics of ground water $(\mathrm{GW})$ and $100 \%$ wastewater $(100 \% \mathrm{WW})$. All determinations in mg. $\mathrm{l}^{-1}$ or as specified.

\begin{tabular}{|c|c|c|c|}
\hline Determinations & GW & WW & FAO acceptable level \\
\hline $\mathrm{pH}$ & 7.30 & 8.00 & $6.5-8.4^{\mathrm{a}}$ \\
\hline $\mathrm{EC}\left(\mu\right.$ mhos $\left.\mathrm{cm}^{-1}\right)$ & 700.00 & 1310.00 & $0.25-3.0^{\mathrm{a}}$ \\
\hline TS & 955.00 & 1550.00 & $2200^{c}$ \\
\hline TDS & 560.00 & 1060.00 & $<2000^{\mathrm{a}}$ \\
\hline TSS & 400.00 & 576.00 & - \\
\hline BOD & 16.25 & 105.55 & $<25^{\mathrm{b}}$ \\
\hline COD & 65.45 & 150.25 & $30-160^{b}$ \\
\hline $\mathrm{NO}_{3}-\mathrm{N}$ & 0.83 & 2.75 & $<10.0^{\mathrm{a}}$ \\
\hline $\mathrm{NH}_{4}-\mathrm{N}$ & 0.11 & 4.45 & $5.0^{\mathrm{a}}$ \\
\hline $\mathrm{Na}^{+}$ & 20.56 & 59.35 & - \\
\hline $\mathrm{K}^{+}$ & 4.94 & 20.44 & $<2.0^{\mathrm{a}}$ \\
\hline $\mathrm{Ca}^{++}$ & 15.45 & 52.35 & $<400^{\mathrm{a}}$ \\
\hline $\mathrm{Mg}^{++}$ & 27.35 & 118.72 & $<61^{\mathrm{a}}$ \\
\hline $\mathrm{Cl}^{-}$ & 55.25 & 113.22 & $<350^{\mathrm{a}}$ \\
\hline $\mathrm{CO}_{3}^{--}$ & 54.54 & 147.74 & - \\
\hline $\mathrm{HCO}_{3}^{-}$ & 105.33 & 80.48 & $<610^{\mathrm{a}}$ \\
\hline $\mathrm{SO}_{4}^{--}$ & 30.86 & 88.95 & - \\
\hline $\mathrm{PO}_{4}^{---}$ & 0.36 & 1.24 & $<2.0^{\mathrm{a}}$ \\
\hline $\mathrm{Cu}$ & - & 0.209 & $0.20^{\mathrm{d}}$ \\
\hline $\mathrm{Cd}$ & - & 0.009 & $0.01^{\mathrm{d}}$ \\
\hline $\mathrm{Ni}$ & - & 0.331 & $0.20^{\mathrm{d}}$ \\
\hline $\mathrm{Zn}$ & - & 0.153 & $2.0^{\mathrm{d}}$ \\
\hline $\mathrm{Cr}$ & - & 0.039 & $0.10^{\mathrm{d}}$ \\
\hline $\mathrm{Pb}$ & - & 0.028 & $5.0^{\mathrm{d}}$ \\
\hline
\end{tabular}

Note: ${ }^{a}$ Ayers and Westcot, (1994); ${ }^{b}$ Pescod, (1992); ${ }^{c}$ Indian Standard Institution (1974); ${ }^{\mathrm{d}}$ Awasthi, (2000).

In India, vegetable consumption is many times more than the European countries due to the vegetarian food habit of a large proportion of the population, and the lower cost of the common vegetables compared to meat, fish, egg and milk products. It is also important that, compared to other crops, many vegetables can be grown throughout the year and be marketed regularly, due to a short life-cycle.

Fenugreek (Trigonella foenum-graecum L.) is used fresh or dried, as spice (seeds) and vegetables (fresh leaves, sprouts and microgreens). Fenugreek leaves contain calcium, phosphorus and iron. Seeds are bitter in taste and have been known over 2500 years for their medicinal qualities (chronic dysentery, diarrhoea, chronic cough, enlargement of liver and spleen). The seeds contain the steroidal substance "diosgenin" which is used as a starting material in the synthesis of sex hormone as oral contraceptive. The study examined application of urban wastewater for irrigation and its effect on Fenugreek supplemented with nitrogen.

\section{MATERIALS AND METHODS}

Wastewater (WW) was collected in $50 \mathrm{~L}$ Jerry cans for watering the pots, as and when required, from the drain running along the Aligarh Mathura road, $6 \mathrm{~km}$ away from the Department. The water analyzed at the start and end of each experiment. Tap water was used as the control (GW) pumped directly from under the earth's surface and stored in syntax water tanks. The water types were analyzed for various physicochemical www.tropicalplantresearch.com 
characteristics (Table 1) following standard procedures (APHA 1998). Determination of heavy metals in the wastewater samples was with an Atomic Absorption Spectrophotometer (SENSAA GBC Avanta var. 2.02, Aligarh, India) according to the method of Ademoroti (1996). Microbiological examination of wastewater was conducted in the Microbiology Laboratory, Department of Agricultural Microbiology, Aligarh Muslim University, Aligarh, following quality guidelines of WHO (1989) and FAO (1992).

Before sowing, samples of the sandy loam soil were randomly accumulated from each pot, air-dried, mixed well, ground in a mortar and pestle, and passed through a $2 \mathrm{~mm}$ sieve before analysis. Soil $\mathrm{pH}$ and electrical conductivity were determined following the procedure of Jackson (1958). Organic matter was measured using the method described by Walkley \& Black (1934). Estimation of carbonates and bicarbonates was followed Richards (1954). Nitrate nitrogen was estimated according to Ghosh et al. (1983). Phosphorus was measured following Olsen et al. (1954); potassium was estimated following Jackson (1958). Soil cation exchange capacity was determined following Ganguly (1951). Soil heavy metals were determined following Lindsey \& Norwell (1978).

The experiment was conducted in the November 2010 to March 2011. The experiment was a completely randomized design replicated 3 times with main treatment of $100 \%$ urban wastewater (WW) and groundwater $(\mathrm{GW})$. Doses of NPK fertilizer $\left(\mathrm{N}_{0} \mathrm{P}_{0} \mathrm{~K}_{0}, \mathrm{~N}_{20} \mathrm{P}_{30} \mathrm{~K}_{30}, \mathrm{~N}_{40} \mathrm{P}_{30} \mathrm{~K}_{30}\right.$ and $\left.\mathrm{N}_{60} \mathrm{P}_{30} \mathrm{~K}_{30}\right)$ were mixed into the soil with the fertilizers from urea, single super phosphate and muriate of potash.

Effects of treatment were determined by measurement of plant: length, fresh and dry weights, numbers of leaves, leaf area, leaf fresh and dry weights, proline content, malondialdehyde content and enzymatic antioxidants (catalase, peroxidase and superoxide dismutase) at vegetative, flowering and fruiting stages at 30 , 60 and 90 DAS, respectively. Plants were uprooted and lengths of the main tap root and shoot were measured. To assess dry mass, plants were dried for about $72 \mathrm{hrs}$ in a hot air oven (forced air oven) maintained at $80^{\circ} \mathrm{C}$ and then weighed. After separating all the leaves at the petiole and stem junction, leaf area was measured using a leaf area meter (LA 211, Systronics, India). Proline content in fresh leaves was estimated following the procedure of Bates et al. (1973). The level of lipid peroxidation products in leaves was determined as malondialdehyde content by a modified version of the method described by Cakmak \& Horst (1991). Catalase activity (EC 1.11.1.6) was measured according to Aebi (1984). SOD activity (EC 1.15.1.1) was estimated by recording the decrease in absorbance of superoxide nitroblue tetrazolium complex by the enzyme (Sen Gupta $e t$ al. 1993). The method of Bergmeyer et al. (1974) was used to measure oxidation of pyrogallol to purpurogallin by peroxidase.

The data were analyzed according to Panse \& Sukhatme (1985) using a two-way analysis of variance after Steel \& Torrie (1962) SPSS (ver. 11.0, Chicago, IL). If interactions were significant they were used to explain results using Duncan Multiple Range Test (Duncan 1955).

\section{RESULTS}

The physicochemical and microbiological properties of water types varied (Table 1). Electrical conductivity, total solids, total dissolved solids, BOD, COD, nitrate nitrogen, ammonia nitrogen, sodium, calcium, magnesium, chlorine, carbonate, sulphate and phosphate had higher values in wastewater than in groundwater (Table 1). Contents of $\mathrm{Cu}, \mathrm{Cd}, \mathrm{Zn}, \mathrm{Cr}$ and $\mathrm{Pb}$ were within permissible limits; the $\mathrm{Ni}$ content exceeded permissible limits. The presence of microorganisms in wastewater from highest to lowest was faecal coliforms $\left(7.2 \times 10^{2} \mathrm{cfu} / 100 \mathrm{~mL}\right)$, total heterotrophic bacteria $\left(2.83 \times 10^{6} \mathrm{cfu} / 100 \mathrm{~mL}\right)$, total coliforms $\left(1.9 \times 10^{3} \mathrm{cfu} / 100 \mathrm{~mL}\right)$ and Salmonella-Shigella sp. $\left(1.3 \times 10^{2} \mathrm{cfu} 100 / \mathrm{mL}\right)$.

Soil characteristics prior to the study and after the study varied (Table 2). The $\mathrm{pH}$ of the pre-sowing soil was desirable in agricultural soil. In pots irrigated with wastewater, the $\mathrm{pH}$ of soil extract decreased from before sowing to after harvesting. The organic carbon of wastewater irrigation was higher than well water and soil irrigated with wastewater had higher organic carbon than pre-sowing soil. This indicates that wastewater irrigation helps improve fertility after crop harvest. Wastewater provided essential nutrients to the soil and the crop because wastewater irrigated soil had more nitrogen, phosphorus and potassium than pre-sowing soil. Concentrations of heavy metals were within permissible limits (Awasthi 2000).

The wastewater and nitrogen combination, $\mathrm{WW} \times \mathrm{N}_{20}$, was most effective as it produced the longest plants, higher plant fresh and dry weights, more leaves, higher leaf area, and higher leaf fresh and dry weight at the 3 growth stages (Figs. 1, $2 \& 3$ ). There was an increase of $65.57 \%$ at 30 DAS, $35.06 \%$ at 60 DAS and $35.03 \%$ at 90 DAS in plant length over the $\mathrm{GW} \times \mathrm{N}_{0}$. For plant fresh weight, interactions were significant only at fruiting www.tropicalplantresearch.com 
stage, where $\mathrm{WW} \times \mathrm{N}_{20}$ and $\mathrm{WW} \times \mathrm{N}_{40}$ had similar values with increases of 35.14 and $29.13 \%$ over $\mathrm{GW} \times \mathrm{N}_{0}$, respectively. The best combination increased $54.89,52.13$ and $51.81 \%$ in plant dry weight over $\mathrm{GW} \times \mathrm{N}_{0}$ at the 3 growth stages. Among interactions, $\mathrm{WW} \times \mathrm{N}_{20}$ increased leaf number by $35.16,35.58$ and $35.53 \%$ over $\mathrm{GW} \times \mathrm{N}_{0}$ at the successive stages. For leaf area, $\mathrm{WW} \times \mathrm{N}_{20}$, produced increases of $34.95,35.29$ and $35.37 \%$ over $\mathrm{GW} \times \mathrm{N}_{0}$ at the 3 growth stages, respectively. Interactions were significant at vegetative and flowering stages in leaf fresh weight. The $\mathrm{WW} \times \mathrm{N}_{20}$ had the best causing increases of 40.27 and $39.13 \%$ over $\mathrm{GW} \times \mathrm{N}_{0}$ at the vegetative and flowering stages, respectively. This optimum combination recorded an increase of 39.2, 35.95 and $37.06 \%$ in leaf dry weight over $\mathrm{GW} \times \mathrm{N}_{0}$ at the 3 growth stages, respectively. The combinations $\mathrm{WW} \times \mathrm{N}_{20}$ and $\mathrm{WW} \times \mathrm{N}_{40}$ were similar. The $W W \times N_{0}$ combination was similar with $G W \times N_{20}, G W \times N_{40}$ and $G W \times N_{60}$. The linear regression curves worked out for plant height with leaf number and leaf area with leaf fresh weight favour the present findings (Fig. 4).

Table 2. Physicochemical characteristics of soil collected before sowing. All determinations in mg. $\mathrm{l}^{-1}$ in 1:5 (soil-water extract) or as specified.

\begin{tabular}{|c|c|c|c|}
\hline Determinations & Pre-sowing soil & $\begin{array}{c}\text { After harvest } \\
\text { (soil layer irrigated with wastewater) }\end{array}$ & Normal Range \\
\hline Texture & Sandy Loam & Sandy Loam & - \\
\hline CEC (meq $100 \mathrm{~g}^{-1}$ soil) & 3.32 & 3.92 & - \\
\hline $\mathrm{pH}$ & 7.74 & 6.85 & - \\
\hline Organic Carbon $(\%)$ & 0.419 & 1.15 & - \\
\hline $\mathrm{EC}\left(\mu \mathrm{mhos} \mathrm{cm}^{2}\right)$ & 242 & - & - \\
\hline TDS & 758 & - & - \\
\hline $\mathrm{NO}_{3}-\mathrm{N}\left(\mathrm{g} \mathrm{kg}^{-1}\right.$ soil $)$ & 0.352 & 0.283 & - \\
\hline Phosphorus ( $\mathrm{g} \mathrm{kg}^{-1}$ soil) & 0.109 & 0.151 & - \\
\hline Potassium & 8.2 & 11.6 & - \\
\hline Calcium & 27.14 & 23.89 & - \\
\hline Magnesium & 16.49 & 12.94 & - \\
\hline Chloride & 29.47 & - & - \\
\hline Carbonate & 19.34 & - & - \\
\hline Bicarbonate & 92.43 & - & - \\
\hline Sodium & 14.11 & 15.02 & - \\
\hline Sulphate & 17.32 & & - \\
\hline $\mathrm{Cu}$ & - & 1.11 & $135-270$ \\
\hline $\mathrm{Cd}$ & - & 0.22 & $3-6$ \\
\hline $\mathrm{Ni}$ & - & 0.75 & $75-150$ \\
\hline $\mathrm{Zn}$ & - & 2.09 & $300-600$ \\
\hline $\mathrm{Cr}$ & - & 0.053 & - \\
\hline $\mathrm{Pb}$ & - & 0.72 & $250-500$ \\
\hline
\end{tabular}

Proline content increased with increasing nitrogen dose as well as with wastewater; the $\mathrm{WW} \times \mathrm{N}_{60}$ interaction caused an increase of $24.09,27.27$ and $22.84 \%$ over $\mathrm{GW} \times \mathrm{N}_{0}$ at 3 stages, respectively. Wastewater treated plants had increased malondialdehyde content over GW irrigated plant. However, malondialdehyde content declined with increase in nitrogen. Among combinations, $\mathrm{WW} \times \mathrm{N}_{0}$ and $\mathrm{WW} \times \mathrm{N}_{20}$ and $\mathrm{WW} \times \mathrm{N}_{40}$ were best and similar (Fig. 5).

Wastewater irrigation increased the activity of catalase, peroxidase and superoxide dismutase. Nitrogen dose also positively influenced the enzyme activity with most activity under $\mathrm{N}_{60}$. The $\mathrm{WW} \times \mathrm{N}_{60}$ combination produced increases of $25.19,20.74$ and $22.58 \%$ in catalase over $\mathrm{GW} \times \mathrm{N}_{0}$ at the 3 samplings, respectively. However, this combination increased peroxidase by $24.56 \%$ at the vegetative stage, and 20.04 and $18.91 \%$ in superoxide dismutase at vegetative and flowering stages over $\mathrm{GW} \times \mathrm{N}_{0}$, respectively. The interactions were not significant at flowering and fruiting stages for peroxidase but were significant at the flowering stage for superoxide dismutase (Fig. 6). The proline content and antioxidant enzymes increased with the combination of $\mathrm{WW} \times \mathrm{N}_{60}$. The proline content was positively correlated with CAT $\left(\mathrm{r}^{2}=0.9479\right)$, POD $\left(\mathrm{r}^{2}=0.8991\right)$ and SOD $\left(r^{2}=0.9056\right)$ (Fig. 7).

www.tropicalplantresearch.com 

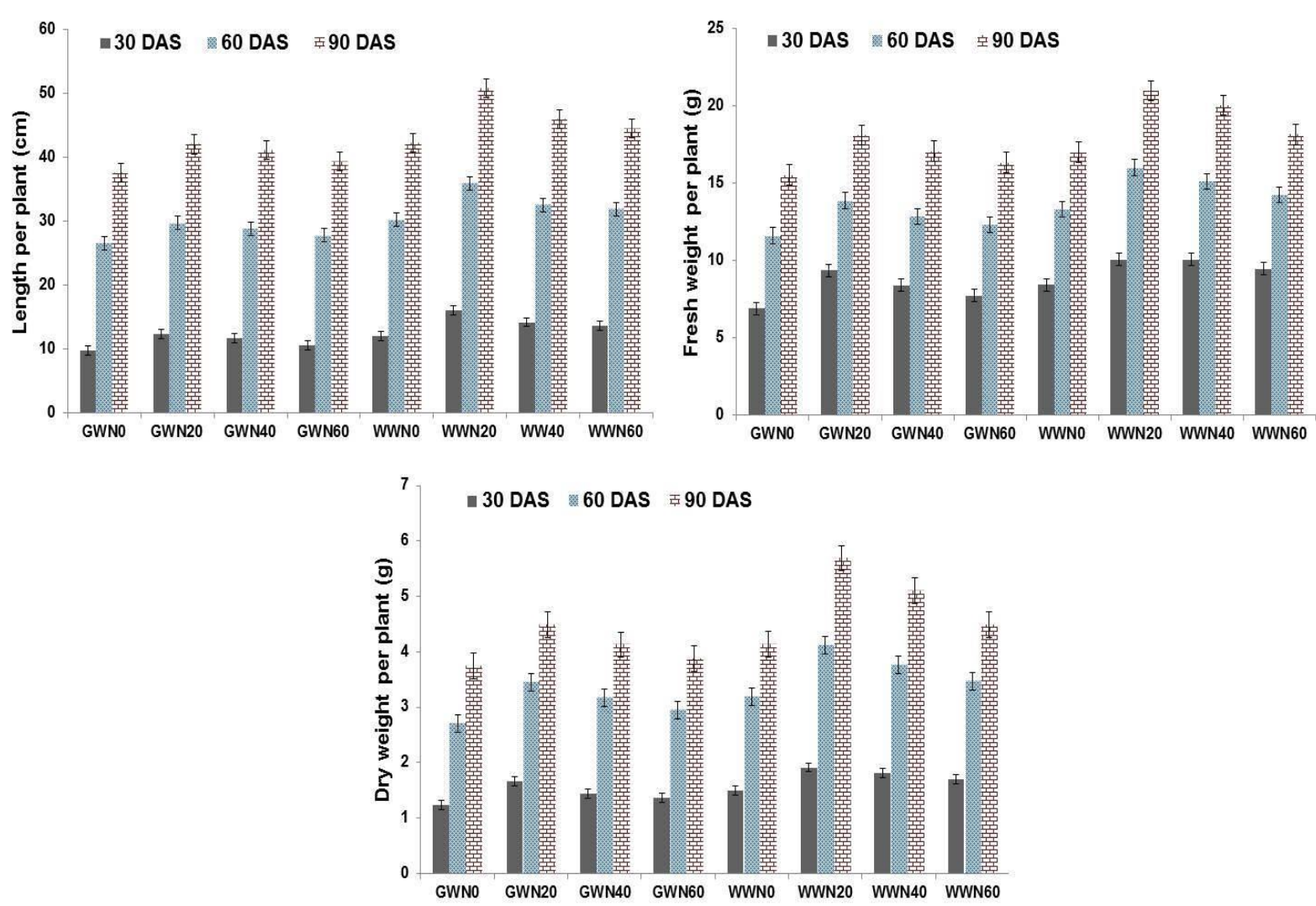

Figure 1. Effect of waste water on length, fresh weight and dry weight/plant of fenugreek supplemented with different nitrogen at 30,60 and 90 DAS.
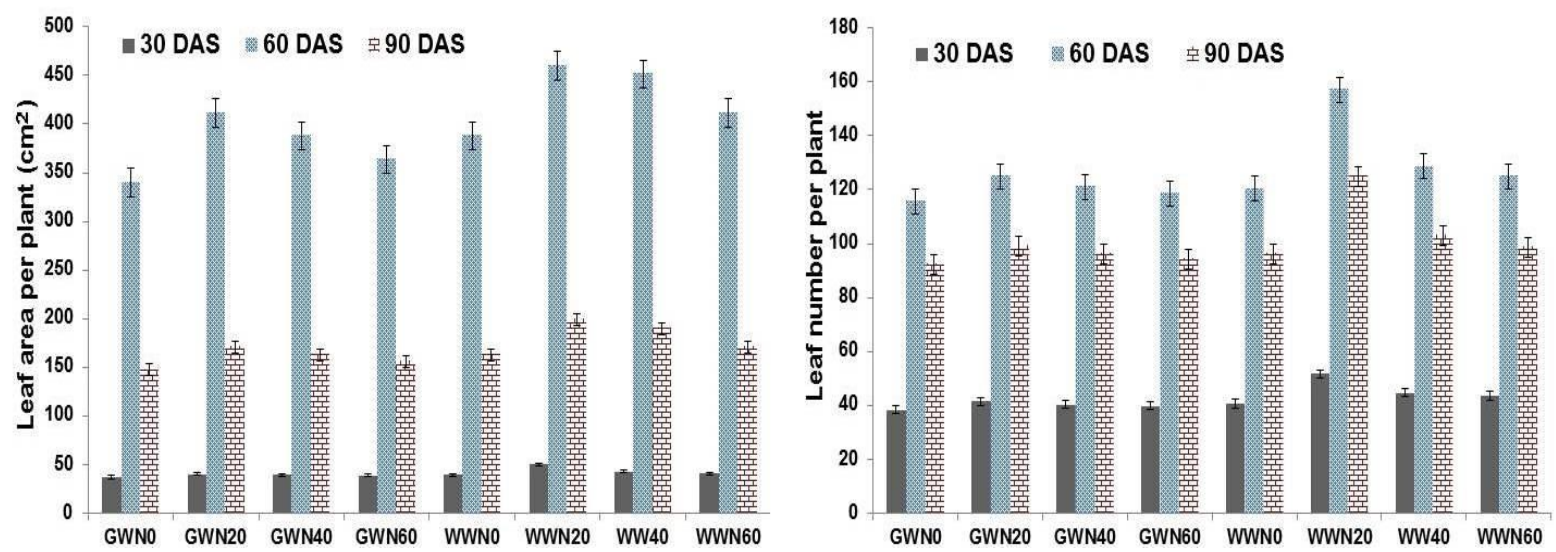

Figure 2. Effect of waste water on leaf number and leaf area/plant of fenugreek supplemented with nitrogen at 30,60 and 90 DAS.
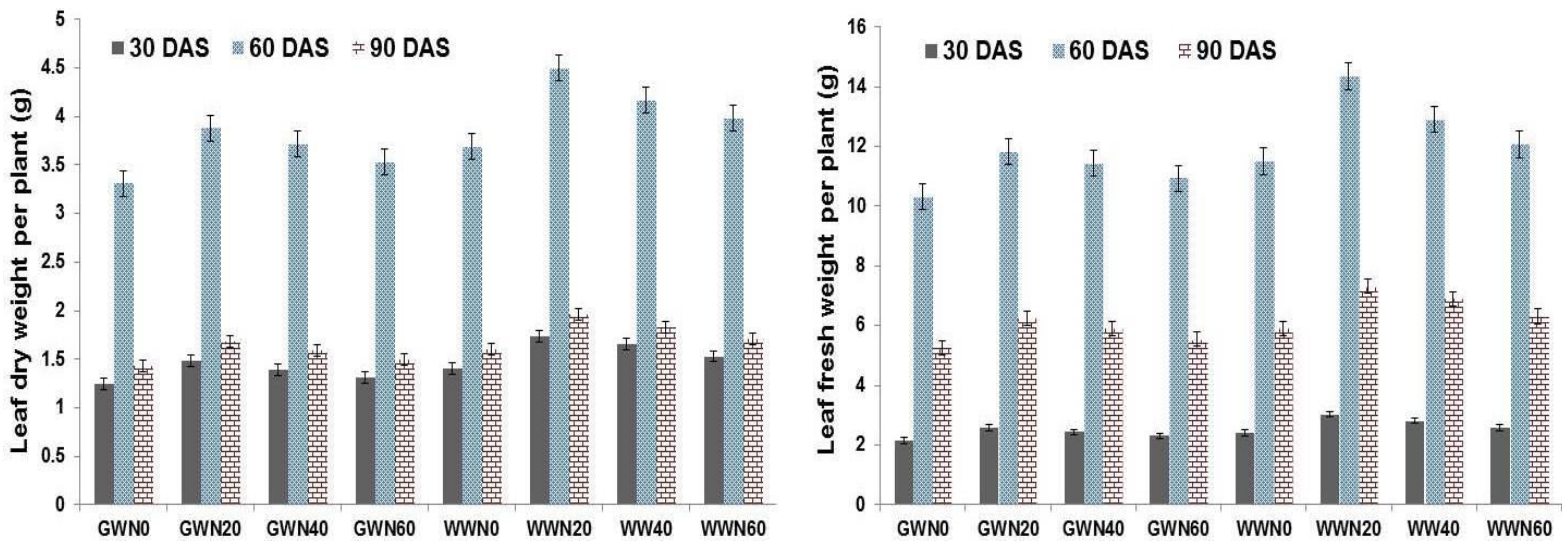

Figure 3. Effect of waste water on leaf fresh weight and leaf dry weight/plant of fenugreek supplemented with nitrogen levels at 30,60 and 90 DAS (at 30 DAS, leaf dry weight $\times 10$ ). 

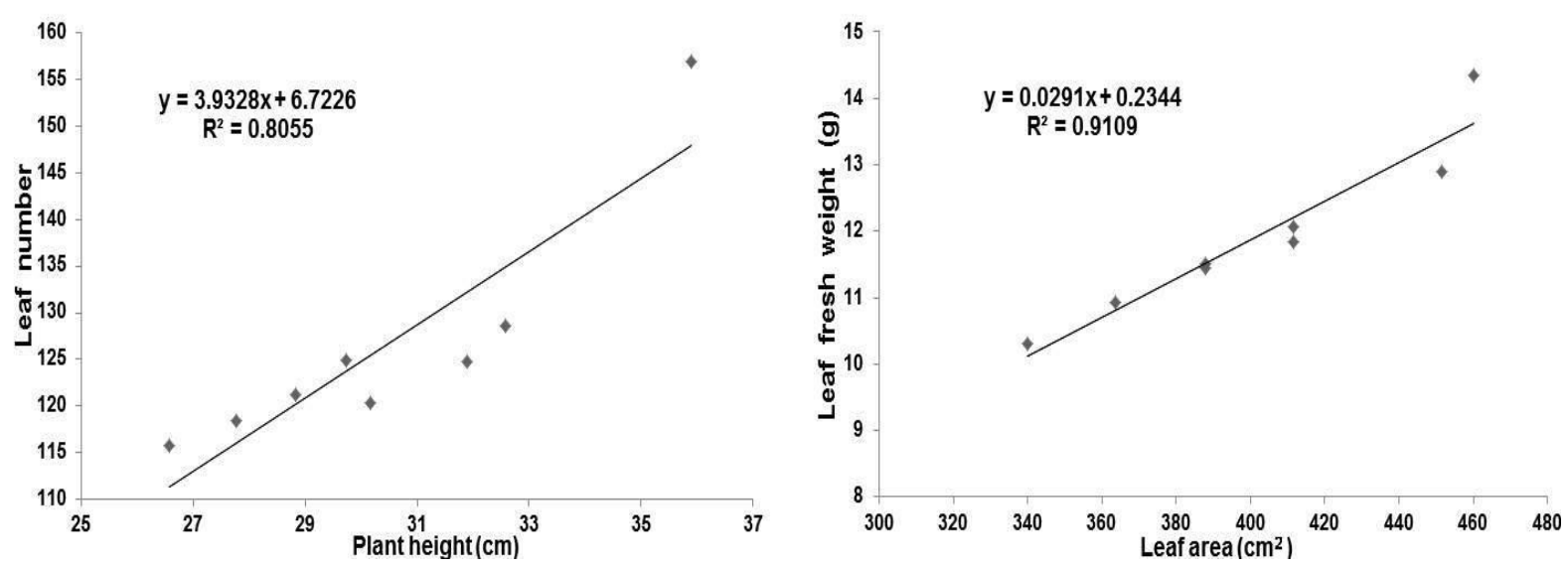

Figure 4. Linear regression curve of fenugreek showing correlation of plant height with leaf number and leaf area with leaf fresh weight at 60 DAS.
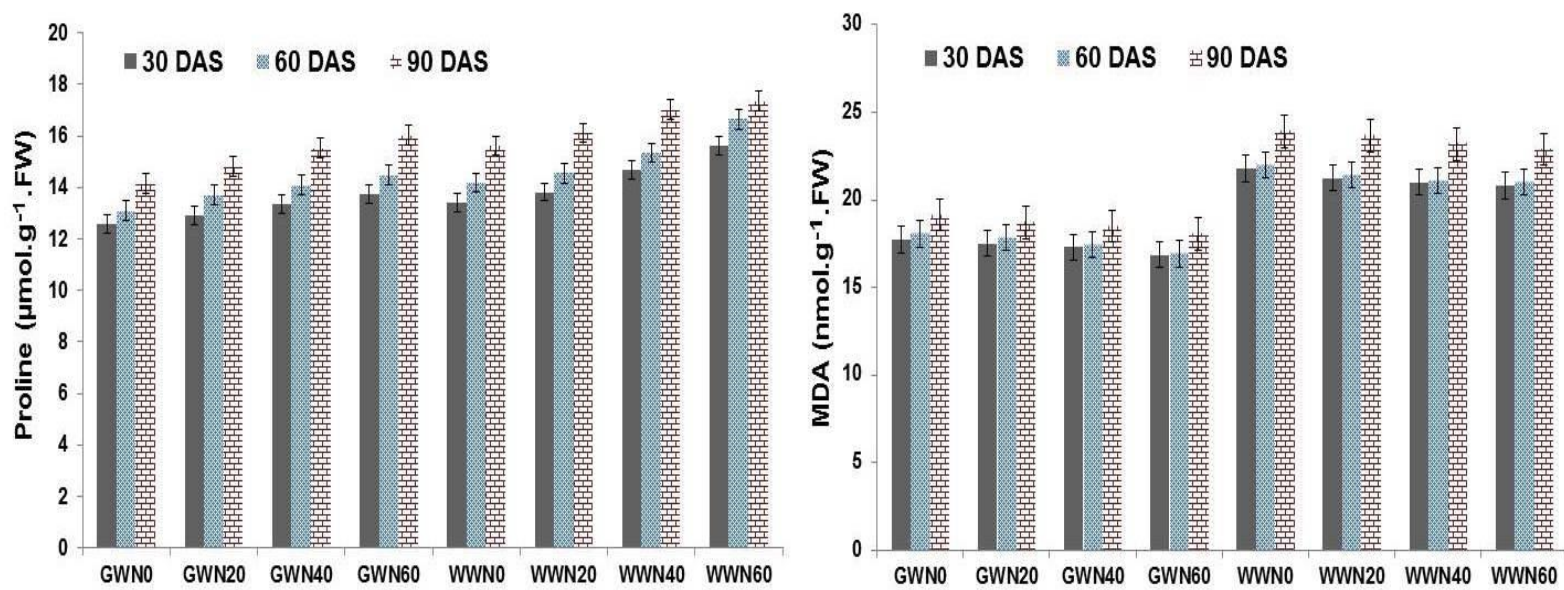

Figure 5. Effect of waste water on proline and malondialdehyde contents of fenugreek supplemented with nitrogen at 30, 60 and 90 DAS.
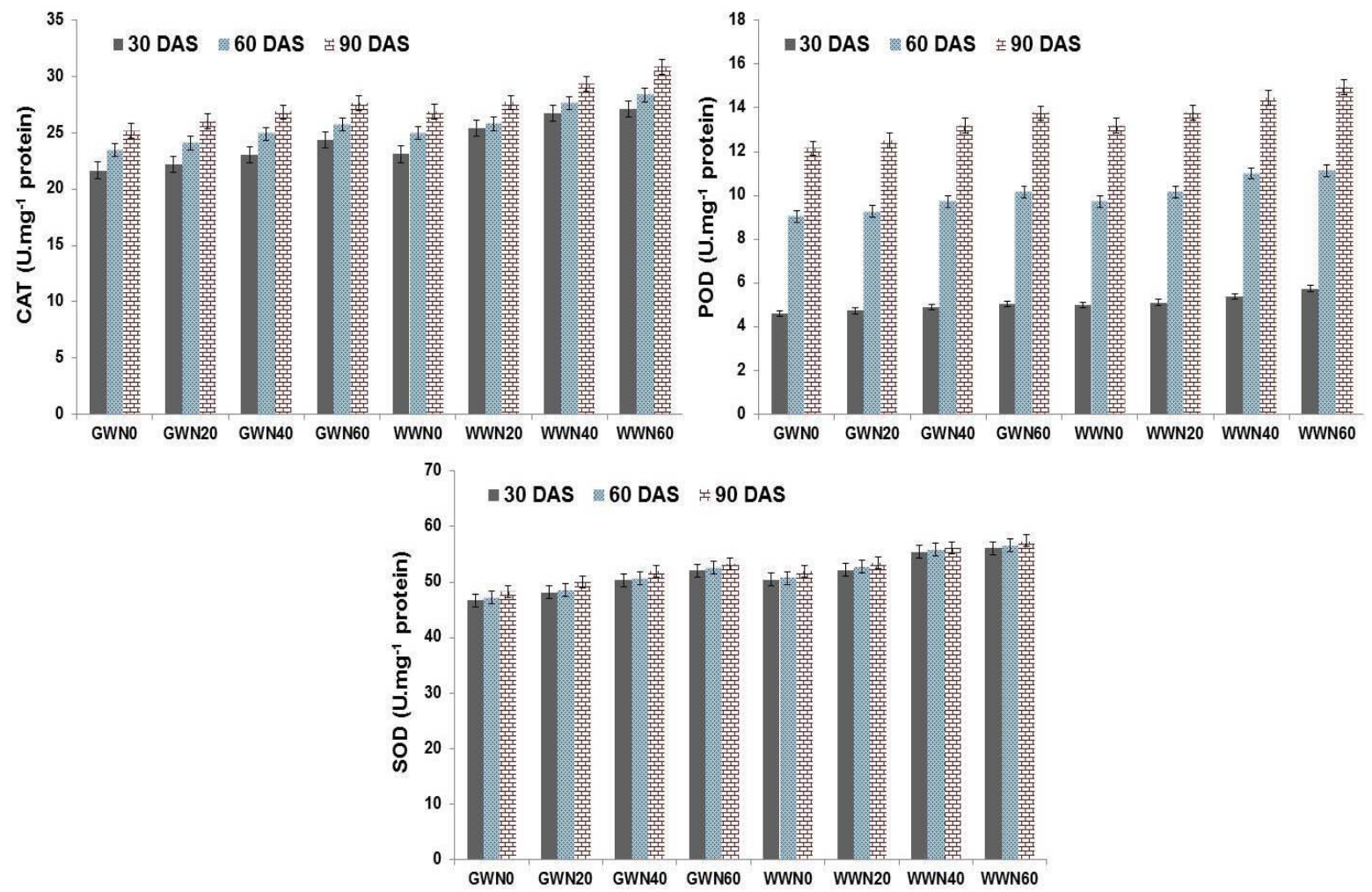

Figure 6. Effect of waste water on catalase, peroxidase and superoxide dismutase activity of fenugreek supplemented with nitrogen.

www.tropicalplantresearch.com 

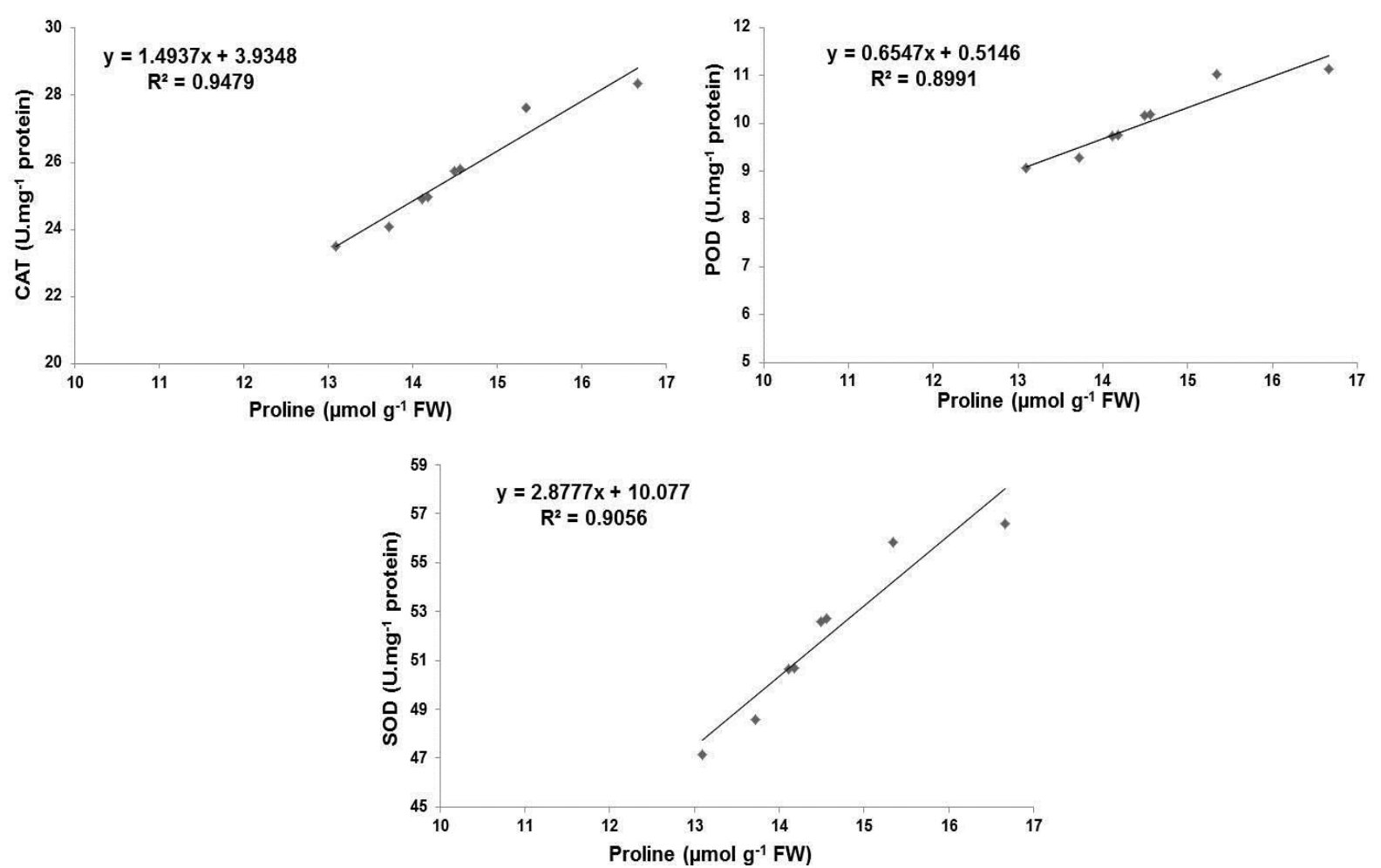

Figure 7. Linear regression curve of fenugreek showing correlation of proline with catalase, peroxidase and superoxide dismutase at 60 DAS.

\section{DISCUSSION}

The maximum values of various parameters were recorded with $100 \%$ concentration of wastewater which was black in color. The higher value of TDS is associated with higher EC of wastewater (Bhargava et al. 2008). The $\mathrm{Cl}^{-}, \mathrm{CO}_{3}^{-2}$ and $\mathrm{HCO}_{3}{ }^{-}$were within the permissible limits (ISI 1974, Pescod 1992, Ayers \& Westcot 1994). High BOD, $\mathrm{COD}, \mathrm{NO}_{3}{ }^{-}$and $\mathrm{PO}_{4}^{-3}$ might be due to the presence of high oxidizable organic matter and rapid consumption of dissolved inorganic materials (Biswas et al. 2009, Kumar \& Chopra 2012). The TSS content contributed to high salinity. Heavy metals at high levels in water bodies could cause toxicity to aquatic life (Zyadah \& Abdul-Bakky 2000, Indra \& Sivaji 2006) and buildup in river sediments (Singh et al. 1997). Total bacterial count and most probable number in wastewater are likely due to higher organic load of wastewater (Kumar \& Chopra 2012). The $\mathrm{pH}$ is an important parameter as many nutrients are available for plant uptake only at a particular $\mathrm{pH}$ range. A pH value of 6.0-8.2 supports bacterial activity and is favourable for maximum yield. A shift in $\mathrm{pH}$ outside that range renders nutrients less available, even though they remain in the soil. Under acidic conditions, iron, aluminium, manganese, and heavy metals become highly soluble and may create problems for plants (Charman \& Murphy 1991). The higher concentration of $\mathrm{Na}$ in the soil after effluent irrigation may be associated with the presence of high concentration of carbonate and bicarbonate in the effluent (Thompson et al. 2001). Reduction in water infiltration can occur when irrigation water contains high sodium relative to the calcium and magnesium content. This condition is called sodicity which reduces soil permeability (Kelley 1951). The overall increase in nitrogen is likely due to the nitrate and ammonium ions in wastewater. Irrigation with wastewater generally adds significant quantities of salts to the soil.

The beneficial effect on growth may be attributed to the nutrients present in wastewater (Table 1). However, reduced growth at higher concentrations may be due to the accumulation of salt which causes increased electrical conductivity (EC) with a link between EC and reduced plant growth (Kumar \& Chopra 2012). The source of wastewater was diluted urban sewage which appears to be beneficial for the development of fenugreek because properly diluted wastewater can minimize the hazards of heavy metals (Pathak et al. 1999). Use of diluted wastewater from the same source produced beneficial effects on Triticosecale Wittm. (Shah et al. 2005), Lens culinaris Medikus (Tabassum et al. 2007a), Brassica juncea L. (Tabassum et al. 2007b), Abelmoschus esculentus (L.) Moench (Kausar 2009, Faizan et al. 2014, Kausar \& Faizan 2015), Cicer arietinum L. (Tak et al. 2010, 2012, 2013), Triticum aestivum L. (Akhtar et al. 2012), Capsicum annuum L. (Iqbal et al. 2012, Chalkoo et al. 2014, Iqbal et al. 2015). 
Improvement in growth might be due to the presence of nitrogen. Fenugreek responded better to relatively low nitrogen dose because it is a leguminous crop and able to fulfill nitrogen needs by symbiotic nitrogen fixation. However, the process of symbiosis takes time to establish and became fully operative and the nitrogen accumulated in this manner is only available to the soil when the legume plant dies. During early plant growth, a low starter dose of nitrogen is necessary because higher doses hinder nodule formation (Mann 1968, Arrese-Igor et al. 1997, Ram \& Verma 2001, Shahroz 2009). Other reports concerning nitrogen application on the same crop differ (Chaudhary 1999a, b, Sharma 2000, Thapa \& Maity 2003, Datta et al. 2005, Tuncturk et al. 2011) where comparatively higher rates of nitrogen were reported.

Nitrogen is an important nutrient required in large amounts by plants. It is an integral constituent of proteins, nucleic acids, chlorophyll, co-enzymes, phytohormones and secondary metabolites. The availability of $\mathrm{N}$ to roots is therefore a decisive factor for plant growth (Marschner 2012). The urban wastewater used for irrigation contained nitrogen in the ionic forms, $\mathrm{NH}_{4}{ }^{+}$and $\mathrm{NO}_{3}{ }^{-}$and further supplementation of nitrogen in the form of urea yielded nitrate rapidly within a few days which is absorbed by plants possibly contributing to a cumulative effect on growth (James 2010).

Proline is an amino acid that easily accumulates in plants under stress and is a marker of imbalance in a metabolic pathway. It also functions as an osmolyte to alleviate damage caused by biotic or abiotic stresses (Ashraf \& Foolad 2007, Chandra et al. 2009, Myriam et al. 2009, Bedouh \& Bekhouche 2012, Kumar et al. 2012a, b). Resistant plants accumulate more proline than less resistant plants (Naidu et al. 1992). Accumulation of proline preserves the structure and activity of protein, reduces enzyme denaturation and protects biomembranes from damage by inactivating hydroxyl radicals or other reactive chemical species (Pollard \& Wyn Jones 1979, Smirnoff \& Cumbes 1989, Saradhi et al. 1995). Proline accumulates in plants exposed to heavy metal stress (Zhao 2011, Bauddh \& Singh 2012a, b). Fenugreek irrigated with wastewater exhibited increase in the proline content. The wastewater contained heavy metals that cause stress to plants likely increasing proline content. Heavy metal induced proline accumulation has been reported (Lalk \& Dorfling 1985, Bhattacharjree \& Mukherjee 1994, De \& Mukherjee 1998. Handique \& Handique 2009, Kumar et al. 2015). Proline accumulation helps the plant to withstand the heavy metal stress by protecting the key enzyme such as glucose-6-phosphate dehydrogenase and nitrate reductase from being inactivated by toxic heavy metal ions by forming metal-proline complex (Handique \& Handique 2009). In this study, proline content increased with increased nitrogen application. This may be because it is a nitrogen-storage compound (Ahmad \& Hellebust 1988) and that synthesis and accumulation of proline are stimulated by nitrogen supply (Sanchez et al. 2002). This result is in agreement with the findings of many workers (Naidoo \& Naidoo 2001, Sanchez et al. 2001, 2002, Zhao \& Liu 2009, Ahmadi et al. 2010, Wang et al. 2011).

Malondialdehyde content (MDA) or thiobarbituric acid reactive substances (TBARS) is the decomposition product of polyunsaturated fatty acids of biomembranes obtained when reactive oxygen species (ROS) initiates the process of lipid peroxidation, which is considered an indication of oxidative stress in plants (Gosset et al. 1994, Blokhina et al. 2003). Production of the ROS superoxide radical $\left(\mathrm{O}_{2}{ }^{-}\right)$, hydrogen peroxide $\left(\mathrm{H}_{2} \mathrm{O}_{2}\right)$ and hydroxyl radical $\left(\mathrm{OH}^{-}\right)$increases as a result of abiotic stress such as can occur with heavy metal toxicity, salinity and drought in plants. Under normal conditions, these ROS are well regulated by cell metabolism but under abiotic stress, they may exceed the scavenging capacity of the antioxidant system. The wastewater contained heavy metals which may enhance the level of $\mathrm{H}_{2} \mathrm{O}_{2}$ which can result in the formation of hydroxyl radicals that can cause lipid peroxidation (Loggini et al. 1999). Oxidative damage to bio-membranes of plants can be primarily attributed to the presence of $\mathrm{Cd}$, a redox active metal catalyzing the generation of hydroxyl radicals and $\mathrm{O}_{2}^{-}$(Arora et al. 2002). The non-redox metals $\mathrm{Zn}, \mathrm{Ni}, \mathrm{Cr}, \mathrm{Cu}$ and $\mathrm{Pb}$ do not produce ROS directly but generate oxidative stress by interfering with the plant's antioxidant defence system (Garnczarska \& Ratajczak 2000, Aravind \& Prasad 2003, Panda \& Choudhary 2005). These metals might have contributed to increased MDA levels (Olorunfemi \& Lolodi 2011). Reduction of MDA content due to nitrogen application was probably due to increased activity of antioxidant enzymes (Shin et al. 2005, Zhang et al. 2007, Zhao \& Liu 2009, Lin et al. 2011). Xiao et al. (1998) reported that nitrogen application can improve light reaction of photosynthesis which ultimately leads to the lower ROS production.

Biotic and abiotic stresses affect plants by causing excess accumulation of ROS, which can react with certain biomolecules, and alter or inactivate biochemical activities (Mittler 2002, Mittler et al. 2004, Choudhary et al. 2012). Even under optimal conditions, ROS are generated as by-products of normal metabolism in subcellular components (Asada \& Takahashi 1987, Elstner 1991, Asada 1994, del Rio et al. 1998). These radicals are www.tropicalplantresearch.com 
capable of initiating peroxidation reaction (Bandyopadhyay et al. 1999). The ROS also influence degeneration of DNA, oxidation of deoxyribose sugar, the reforming and breaking of DNA strands and cause mutations (Zhang \& Kirkham 1996, Chirkova et al. 1998). To migrate and repair damage initiated by ROS, plants developed complex antioxidant systems (del Rio et al. 2002). This defense system includes enzymatic and nonenzymatic components. The enzymatic defense system includes the enzymes superoxide dismutase (SOD), catalase (CAT), ascorbic peroxidase (APX), dehydroascorbate reductase (DHAR), and glutathione reductase (GR) (Yordanova et al. 2003). SOD is an enzyme acting as a first line of defence in combating oxidative stress in plants, which dismutates superoxide anions to $\mathrm{H}_{2} \mathrm{O}_{2}$ (Shalini \& Dubey 2003, Mishra et al. 2006, Davies et al. 2009). CAT and POD are involved in building resistance against accumulation and toxicity of hydrogen peroxide by converting $\mathrm{H}_{2} \mathrm{O}_{2}$ to water and oxygen in cells (Msttes 2000). Increases in levels of all antioxidant enzymes occurred in fenugreek irrigated with wastewater. This is likely due to the pollutants present that can lead to oxidative stress causing biochemical changes (Lee et al. 2001, Panda \& Upadhyay 2003, Singh et al. 2003, Fatima \& Ahmad 2005, Baghel 2008, Xu et al. 2010, Olorunfemi \& Lolodi 2011, Jain \& Srivastava 2012, Sangeetha et al. 2012). Application of levels of nitrogen increased CAT, POD and SOD activities in fenugreek. This may be due to the alleviation of heavy metal damage by the nitrogen increased activity of antioxidant enzymes. Williams et al. (1967) suggested that addition of nitrogen in soil increases the formation of $\mathrm{NO}_{3}{ }^{-}$ which decreases soil $\mathrm{pH}$. Lowering $\mathrm{pH}$ increases the solubility of heavy metals and decrease the efficiency of adsorption (Moreno et al. 2000, Zhang et al. 2007, Zhao \& Liu 2009, Ahmadi et al. 2010, Lin et al. 2011).

\section{CONCLUSION}

From the present study we concluded that the wastewater used for irrigation is suitable for fenugreek as the nutritive and toxic chemical elements present in wastewater were accumulated in the soil at low level and this accumulation did not cause any problem to the plants tested. Use of wastewater can provide economic benefits. Substitution of ground water by wastewater at some contents increased growth, proline, malondialdehyde content and antioxidant enzymes. Integrated application of wastewater and fertilizer increased growth and biochemical characteristics in fenugreek. Even if oxidative stress is induced in fenugreek plants irrigated with wastewater, application of $\mathrm{N}$ could provide protection against oxidative stress by increasing the antioxidant protective system.

\section{ACKNOWLEDGEMENTS}

The Authors are thankful to the Head of Botany Department, Aligarh Muslim University, Aligarh, India for his valuable support by providing the necessary facilities.

\section{REFERENCES}

Ademoroti CMA (1996) Standard method for water and effluents analysis. Foludex Press Ltd, Ibadan, Nigeria.

Aebi H (1984) Catalase in vitro. Methods of Enzymology 105: 121-126.

Ahmad I \& Hellebust JA (1988) The relationship between inorganic nitrogen metabolism and proline accumulation in osmoregulatory response of two euryhaline microalgae. Plant Physiology 88: 348-354.

Ahmadi A, Emam Y \& Pessarakli M (2010) Biochemical changes in maize seedlings exposed to drought stress conditions at different nitrogen levels. Journal of Plant Nutrition 33: 541-556.

Akhtar N, Inam A, Inam A \& Khan NA (2012) Effects of city wastewater on the characteristics of wheat with varying doses of nitrogen, phosphorus and potassium. Recent Research in Science and Technology 4: 18-29.

Akponikpe PBI, Wima K, Yacouba H \& Mermoud A (2011) Reuse of domestic wastewater treated in macrophyte ponds to irrigate tomato and eggplant in semi-arid West-Africa: Benefits and risks. Agricultural Water Management 98: 834-840.

APHA (1998) Standard Methods for the Examination of Water and Wastewater, $20^{\text {th }}$ Edition. American Public Health Association, Washington, D.C.

Aravind P \& Prasad MNV (2003) Zinc alleviates cadmium-induced oxidative stress in Ceratophyllum demersum L.: A free floating freshwater macrophyte. Plant Physiology and Biochemistry 41: 391-397.

Arora A, Sairam RK \& Srivastava GC (2002) Oxidative stress and antioxidative system in plants. Current Science 82: 1227-1238.

Arrese-Igor C, Minchin FR, Gordon AJ \& Nath AK (1997) Possible causes of the physiological decline in soybean nitrogen fixation in the presence of nitrate. Journal of Experimental Botany 48: 905-913. 
Asada K (1994) Production and action of active oxygen species in photosynthetic tissue. In: Foyer CH \& Mullmeaux PM (eds) Causes of photo-oxidative stress and amelioration of defense system in plants. CRC Press, Boca Ratton, FL, pp. 77-107.

Asada K \& Takahashi M (1987) Production and scavenging of active oxygen in photosynthesis. In: Kyle DJ, Osmond CB \& Arntzen CJ (eds) Photoinhibition. Elsevier, Amsterdam, pp. 227-287.

Ashraf M \& Foolad MR (2007) Roles of glycine betaine and proline in improving plant abiotic stress resistance. Environmental and Experimental Botany 59: 206-216.

Avemelech Y (1993) Irrigation with sewage effluents: The Israeli experience. Environmental Science \& Technology 23: 2127-2134.

Awasthi SK (2000) Prevention of Food Adulteration Act No. 37 of 1954. Central and State Rules as Amended for 1999, Third edition, Ashoka Law House, New Delhi.

Ayers RS \& Westcot DW (1994) Water quality for agriculture. FAO Irrigation \& Drainage Paper 29 Rev.1. Food and Agriculture Organization of the United Nations, Rome.

Baghel RS (2008) Toxicity of distillery effluent on seed germination, seedling growth and metabolism in Pisum sativum. Research in Environment and Life Sciences 1: 29-32.

Bandyopadhyay U, Das N \& Banerjee RK (1999) Reactive oxygen species: oxidative damage and pathogenesis. Current Science 77: 658-666.

Bates LS, Waldren RP \& Teare ID (1973) Rapid determination of free proline for water-stress studies. Plant Soil 39: 205-207.

Bauddh K \& Singh RP (2012a) Cadmium tolerance and its phytoremediation by two oil yielding plants Ricinus communis L. and Brassica juncea L. from the contaminated soil. International Journal of Phytoremediation 14: 772-785.

Bauddh K \& Singh RP (2012b) Growth, tolerance efficiency and phytoremediation potential of Ricinus communis L. and Brassica juncea L. in salinity and drought affected cadmium contaminated soil. Ecotoxicology and Environmental Safety 85: 13-22.

Bedouh Y \& Bekhouche F (2012) Influence of treated wastewater irrigation on some biochemical parameters of onion (Allium cepa). Annals of Biological Research 3: 4820-4827.

Bergmeyer HU, Gawehn K \& Grassl, M (1974) Enzymatic assay of peroxidase, insoluble. In: Bergmeyer HU (ed) Methods of enzymatic analysis, Vol. I, $2^{\text {nd }}$ edition. Academic Press, Inc., New York, pp. 473-474.

Bhargava RN, Chandra R \& Rai V (2008) Phytoextraction of trace elements and physiological changes in Indian mustard plants (Brassica nigra L.) grown in post methanated distillery effluent (PMDE) irrigated soil. Bioresource Technology 99: 8316-8324.

Bhattacharjee S \& Mukherjee AK (1994) Influence of cadmium and lead on physiological and biochemical responses of Vigna unguiculata (L.) Walp. Seedling germination behavior, total protein, proline content and protease activity. Pollution Research 13: 83-88.

Biswas AK, Mohanty M, Hati KM \& Misra AK (2009) Distillery effluents effect on soil organic carbon and aggregate stability of a vertisol in India. Soil \& Tillage Research 104: 241-246.

Blokhina O, Virolainen E \& Fagerstedt KV (2003) Antioxidants, oxidative damage and oxygen deprivation stress: a review. Annals of Botany 91: 179-194.

Brady NC \& Weil RR (1999) The nature and properties of soils, $12^{\text {th }}$ edition. Pretence Hall, Upper Saddle River, New Jersey.

Cakmak I \& Horst WJ (1991) Effect of aluminium on lipid peroxidation, superoxide dismutase, catalase and peroxidase activities in root tips of soybean (Glycine max). Physiologia Plantarum 83: 463-468.

Chalkoo S, Sahay S, Inam A \& Iqbal S (2014) Application of wastewater irrigation on growth and yield of chilli under nitrogen and phosphorus fertilization. Journal of Plant Nutrition 37: 1139-1147.

Chandra RR, Bhargava N, Yadav S \& Mohan D (2009) Accumulation and distribution of toxic metals in wheat (Triticum aestivum L.) and Indian mustard (Brassica campestris L.) irrigated with distillery and tannery effluents. Journal of Hazardous Materials 162: 1514-1521.

Charman PEV \& Murphy BW (1991) Soils-their properties and management: A soil conservation handbook for New South Wales. Sydney University Press/Soil Conservation Service, NSW. Sydney.

Chaudhary GR (1999a) Response of fenugreek (Trigonella-foenum-graecum) to N, P and Rhizobium inoculation. Indian Journal of Agronomy 44: 424-426. 
Chaudhary GR (1999b) Response of fenugreek (Trigonella foenum-graecum L.) to seed rate and fertilizer application. Indian Journal of Agronomy 44: 427-429.

Chen T \& Chia O (2002) Vegetable growth in polluted soils in China. Environmental Sciences 2: 193-195.

Chirkova TV, Novitskaya LO \& Blokhina OB (1998) Lipid peroxidation and antioxidant systems under anoxia in plants differing in their tolerance to oxygen deficiency. Russian Journal of Plant Physiology 45: 55-62.

Choudhary SP, Oral HV, Bhardwaj R, Yu JQ \& Tran LS (2012) Interaction of brassinosteroids and polyamines enhances copper stress tolerance in Raphanus sativus. Journal of Experimental Botany 63: 5659-5675.

Cisse G (1997) Health impact of the use of polluted water in urban agriculture: The case of market gardening in Ouagadougou. Ph.D. Thesis. Department of Agricultural Engineering, Federal Polytechnic School of Lausanne, Lausanne, Switzerland.

Datta S, Alam K \& Chatterjee R (2005) Effect of different levels of nitrogen and leaf cutting on growth, leaf and seed yield of fenugreek (Trigonella foenum-graecum L.). Indian Journal of Agricultural Science 75: 580581.

Davies LC, Cabrita GJM, Ferreira RA, Carias CC, Novais, JM \& Martins-Dias S (2009) Integrated study of the role of Phragmites australis in azo-dye treatment in a constructed wetland: From pilot to molecular scale. Ecological Engineering 35: 961-970.

De B \& Mukherjee AK (1998) Mercury induced metabolic changes in seedlings and cultured cells of tomato. Geobios 23: 83-88.

del Rio LA, Corpas FJ, Sandalio LM, Palma JM, Gomez M \& Barroso JB (2002) Reactive oxygen species, antioxidant systems and nitric oxide in peroxisomes. Journal of Experimental Botany 53: 1255-1272.

del Rio LA, Pastori G, Palma JM, Sandalio LM, Sevilla F, Corpas FJ, Jimenez J, Lopez-Huertas E \& Hernandez JA (1998) The activated oxygen role of peroxisomes in senescence. Plant Physiology 116: 1195-1200.

Duncan DB (1955) Multiple range and multiple F tests. Biometrics 11: 1-42.

Elstner EF (1991) Mechanisms of oxygen activation in different compartments of plant cells. In: Pell EJ \& Steffen KL (eds) Active oxygen species, oxidative stress and plant. The American Society of Plant Physiologists, Rockville, MD, pp. 13-25.

Faizan S, Kausar S \& Akhtar N (2014) Influence of wastewater application and fertilizer use on growth, photosynthesis, nutrient homeostatis, yield and heavy metal accumulation in okra (Abelmoschus esculentus L. Moench). Pakistan Journal of Biological Sciences 17: 630-640.

Fatima RA \& Ahmad M (2005) Certain antioxidant enzymes of Allium cepa as biomarkers for the detection of toxic heavy metals in wastewater. Science of the Total Environment 346: 256-273.

FAO (1992) Wastewater treatment and use in agriculture. Irrigation Paper 47. Food and Agriculture Organization of the United Nations, Rome, Italy.

Ganguly AK (1951) Base exchange capacity of silica and silicates. Journal of Physical and Colloid Chemistry 55: 1417-1428.

Garnczarska M \& Ratajczak L (2000) Metabolic responses of Lemna minor to lead ions II. Induction of antioxidant enzymes in roots. Acta Physiologiae Plantarum 22: 429-432.

Ghosh AB, Bajaj JC, Hasan R \& Singh D (1983) Soil and water testing methods: A laboratory manual. Indian Agriculture Research Institute, New Delhi.

Gosset DR, Millhollon EP \& Lucas MC (1994) Antioxidant response to $\mathrm{NaCl}$ stress in salt-tolerant and saltsensitive cultivars of cotton. Crop Science 34: 706-714.

Handique GK \& Handique AK (2009) Proline accumulation in lemongrass (Cymbopogon flexuosus Stapf.) due to heavy metal stress. Journal of Environmental Biology 30: 299-302.

ISI (1974) Permissible limits of industrial waste waters discharge into inland surface water. No. 2490. Indian Standard Institution, New Delhi, India.

Indra V \& Sivaji S (2006) Metals and organic components of sewage and sludges. Journal of Environmental Biology 27: 723-725.

Iqbal S, Inam A, Inam A, Ashfaque F \& Sahay S (2017) Potassium and wastewater interaction in the regulation of photosynthetic capacity, ascorbic acid and capsaicin in chilli (Capsicum annuum L.) plant. Agricultural Water Management 184: 201-210.

Iqbal S, Inam A, Inam A, Sahay S \& Chalkoo S (2012) Balance use of inorganic fertilizers on chilli (Capsicum annuит L.) irrigated with wastewater. Biosciences International 1: 82-89. 
Iqbal S, Inam A, Sahay S \& Inam A (2015) Growth, physiological, yield and quality response in Chilli (Capsicum annuиm L.) under wastewater irrigation and different levels of phosphorus. American Journal of Experimental Agriculture 5: 70-81.

Jackson ML (1958) Soil chemical analysis. Prentice Hall, Englewood Cliffs, N.J.

Jain R \& Srivastava S (2012) Nutrient composition of spent wash and its impact on sugarcane growth and biochemical attributes. Physiology and Molecular Biology of Plants 18: 95-99.

James DW (2010) Urea: A low cost nitrogen fertilizer with special management requirements. In: Fertilizer composition and reactions in soils. Utah fertilizer guide. Utah State University Cooperative Extension (extension.usu.edu).

Kausar S (2009) Effect of wastewater on growth and productivity of Okra, M.Phil. Dissertation. Department of Botany, Aligarh Muslim University, Aligarh, India.

Kausar S \& Faizan S (2015) Influence of inorganic fertilizers and wastewater irrigation on growth and yield of Okra (Abelmoschus esculentus L.). In: Siddiqui FA (ed) Population Dynamism and Resource Utilization: Geo-Informatics and Resource Dynamics, Vol III. Academic Publications, pp. 97-105.

Kelley WP (1951) Alkali soils: Their formation properties and reclamation, Reinhold, New York.

Kiziloglu FM, Turan M, Sahin U, Angin I, Anapali O \& Okuroglu M (2007) Effects of wastewater irrigation on soil and cabbage-plant (Brassica oleracea var. capitate cv. yalova-1) chemical properties. Journal of Plant Nutrition and Soil Science 170: 166-172.

Kumar CS, Singh A, Sagar RK, Negi MPS \& Maurya JN (2012a) Impact of exogenous application of indole acetic acid on accumulation of heavy metal and antioxidants in wheat (Triticum aestivum L.) under sewage water irrigation. Recent Research in Science and Technology 4: 16-22.

Kumar CS, Singh A, Sagar RK, Negi MPS \& Maurya JN (2012b) Study of indole acetic acid and antioxidant defense system of wheat grown under sewage water. International Journal of Environmental Sciences 3: 821-832.

Kumar N, Kumar S, Bauddh K, Dwivedi N, Shukla P, Singh DP \& Barman SC (2015) Toxicity assessment and accumulation of metals in radish irrigated with battery manufacturing industry effluent. International Journal of Vegetable Science 21: 373-385.

Kumar V \& Chopra AK (2012) Fertigation effect of distillery effluent on agronomical practices of Trigonella foenum graecum L. (Fenugreek). Environmental Monitoring and Assessment 184: 1207-1219.

Lalk I \& Dorfling K (1985) Hardening, ABA, proline and freezing resistance in the winter wheat varieties. Physiologia Plantarum 63: 287-292.

Lee HD, Kim YS \& Lee CB (2001) The inductive responses of the antioxidant enzymes by salt stress in the rice (Oryza sativa L.). Journal of Plant Physiology 158: 737-745.

Lin T, Zhu X, Zhang F \& Wan X (2011) The detoxification effect of nitrogen on cadmium stress in Populus yunnanensis. Botany Research Journal 4: 13-19.

Lindsey WL \& Norwell WA (1978) Development of a DTPA soil test for zinc, iron, manganese and copper. Soil Science Society of America Journal 42: 421-428.

Loggini B, Scartazza A, Brugnoli, E \& Navmi-Izzo F (1999) Antioxidation defense system, pigment composition and photosynthetic efficiency in two wheat cultivars subjected to drought. Plant Physiology 119: 1091-1100.

Lucho-Constantino CA, Alvarez-Suarez M, Beltran-Hernandez RI, Prieto-Garcia F \& Poggi-Varaldo HM (2005) A multivariate analysis of the accumulation and fractionation of major trace elements in agricultural soils in Hidalgo state, Mexico, irrigated with raw wastewater. Environment International 31: 313-323.

Mann HS (1968) Manuring of pulse crop neglected aspect in poor yield. Indian Farming 17: 7-8.

Marschner P (2012) Mineral nutrition of higher plants, $3^{\text {rd }}$ edition. Academic Press, London, UK.

Mishra S, Srivastava S, Tripathi RD, Kumar R, Seth CS \& Gupta DK (2006) Lead detoxification by coontail (Ceratophyllum demersum L.) involves induction of phytochelatins and antioxidant system in response to its accumulation. Chemosphere 65: 1027-1039.

Mittler R (2002) Oxidative stress, antioxidants and stress tolerance. Trends in Plant Science 17: 405-410.

Mittler R, Vanderauwera S, Gollery M \& Van Breusegem F (2004) Reactive oxygen gene network of plants. Trends in Plant Science 9: 490-498.

Moreno DA, Vfllora G, Pulgar G \& Romero L (2000) Effect of nitrogen and potassium supply on concentration 
of iron and manganese and activities of catalase, peroxidase and aconitase in pepper plants. Journal of Plant Nutrition 23: 1787-1795.

Msttes JM (2000) Effects of antioxidant enzymes in the molecular control of reactive oxygen species toxicology. Toxicology 153: 83-104.

Myriam K, Houria B, Rachid R \& Reda DM (2009) Biochemical changes observed in isolated roots of Phragmites australis treated with industrial wastewater. American-Eurasian Journal of Toxicological Sciences 1: 19-23.

Naidoo G \& Naidoo Y (2001) Effects of salinity and nitrogen on growth, ion relations and proline accumulation in Triglochin bulbosa. Wetlands Ecology and Management 9: 491-497.

Naidu BP, Aspinall D \& Paleg LG (1992) Variability in proline-accumulating ability of barley (Hordeum vulgare L.) cultivars induced by vapor pressure deficit. Plant Physiology 98: 716-722.

Olorunfemi DI \& Lolodi O (2011) Effect of cassava processing effluents on antioxidant enzyme activities in Allium cepa L. Biokemistri 23: 49-61.

Olsen SR, Cole CV, Watanabe FS \& Dean LA (1954) Estimation of available phosphorus in soils by extraction with sodium bicarbonate. Circular No. 939. United States Department of Agriculture, Washington D.C.

Panda SK \& Choudhury S (2005) Chromium stress in plants. Brazillian Journal of Plant Physiology 17: 95102.

Panda SK \& Upadhyay RK (2003) Salt stress injury induces oxidative alterations and antioxidative defiance in the roots of Lemna minor. Biologia Plantarum 48: 249-253.

Panse VG \& Sukhatme PV (1985) Statistical methods for agricultural workers, $4^{\text {th }}$ edition. Indian Council of Agricultural Research, New Delhi.

Pathak H, Joshi HC, Chaudhary A, Chaudhary R, Kalra N \& Dwiwedi MK (1999) Soil amendment with distillery effluent for wheat and rice cultivation. Water Air \& Soil Pollution 113: 133-140.

Pescod MB (1992) Wastewater treatment and use in agriculture. FAO Irrigation \& Drainage Paper No.47, FAO, Rome.

Pollard A \& Wyn Jones RG (1979) Enzyme activities in concentrated solutions of glycinebetaine and other solutes. Planta 144: 291-298.

Ram D \& Verma JP (2001) Effect of level of phosphorus and potash on the performance of seed crop of fenugreek (Trigonella foenum graecum L.) cv. Pusa Early Bunching. Haryana Journal of Horticultural Sciences 30: 249-250.

Richards LA (1954) Diagnosis and improvement of saline alkali soils. Agriculture Handbook No. 60. United States Department of Agriculture, Washington, D.C.

Sahay S, Inam A, Inam A \& Iqbal S (2015) Modulation in growth, photosynthesis and yield attributes of black mustard (B. nigra cv. IC247) by interactive effect of wastewater and fly ash under different NPK levels. Cogent Food and Agriculture 1: Article no. 1087632

Sanchez E, Lopez-Lefebre LR, Garcia PC, Rivero RM, Ruiz JM \& Romero L (2001) Proline metabolism in response to highest nitrogen dosages in green bean plants (Phaseolus vulgaris L. cv. Strike). Journal of Plant Physiology 158: 593-598.

Sanchez E, Ruiz JM \& Romero L (2002) Proline metabolism in response to nitrogen toxicity in fruit of French bean plants (Phaseolus vulgaris L. cv. Strike). Scientia Horticulturae 93: 225-233.

Sangeetha R, Kamalahasan B \& Karthi N (2012) Use of tannery effluent for irrigation: an evaluative study on the response of antioxidant defences in maize (Zea mays). International Food Research Journal 19: 607610.

Saradhi PP, Arora S \& Prasad KVSK (1995) Proline accumulates in plants exposed to UV radiation and protects them against induced peroxidation. Biochemical and Biophysical Research Communications 290: 1-5.

Schneider IF \& Erickson AE (1972) Soil limitations for disposal of municipal waste waters. Michigan State University Research Report No. 195. Michigan, United States.

Sen Gupta A, Webb RP, Holaday AS \& Allen RD (1993) Overexpression of superoxide dismutase protects plants from oxidative stress. Plant Physiology 103: 1067-1073.

Shah RA, Javid S \& Inam A (2005) Effect of sewage irrigation and nitrogen rates on the growth and productivity of triticale. Pollution Research 24: 267-274.

Shahroz B (2009) Response of wastewater to some vegetable crops, Ph.D. Thesis. Department of Botany, Aligarh Muslim University, Aligarh, India.

www.tropicalplantresearch.com 
Shalini V \& Dubey RS (2003) Lead toxicity induces lipid peroxidation and alters the activities of antioxidant enzymes in growing rice plant. Plant Science 164: 645-655.

Sharma SK (2000) Response of nitrogen and spacing on fenugreek seed production. The Horticulture Journal 13: $39-42$.

Shin R, Berg RH \& Schachtman DP (2005) Reactive oxygen species and root hairs in Arabidopsis root response to nitrogen, phosphorus and potassium deficiency. Plant and Cell Physiology 46: 1350-1357.

Singh AB, Biswas AK \& Ramana S (2003) Effect of distillery effluents on plant and soil enzymatic activities and groundnut quality. Journal of Plant Nutrition and Soil Science 166: 345-347.

Singh RP, Dabas S, Choudhary A \& Maheshwari R (1997) Effect of lead on nitrate reductase activity and alleviation of lead toxicity by inorganic salts and 6-benzylaminopurine. Biologia Plantarum 40: 339-404.

Smirnoff N \& Cumbes QJ (1989) Hydroxyl radical scavenging activity of compatible solutes. Photochemistry 28: $1057-1060$.

Steel RGD \& Torrie JH (1962) Principles and Procedures of Statistics, $2^{\text {nd }}$ edition, McGraw-Hill Book Company, New York.

Tabassum D, Azad S \& Inam A (2007a) Utility of city wastewater as a source of irrigation water for mustard. Journal of Industrial Pollution Control 23: 391-396.

Tabassum D, Azad S \& Inam A (2007b) Impact of wastewater on the yield of a pulse crop. Journal of Industrial Pollution Control 23: 279-284.

Tak HI, Ahmad F, Babalola OO \& Inam A (2012) Growth, photosynthesis and yield of chickpea as influenced by urban wastewater and different levels of phosphorus. International Journal of Plant Research 2: 6-13.

Tak HI, Babalola OO, Huyser MH \& Inam A (2013) Urban wastewater irrigation and its effect on growth, photosynthesis and yield of chickpea under different doses of potassium. Soil Science and Plant Nutrition 59: $156-167$.

Tak HI, Inam A \& Inam A (2010) Effects of urban wastewater on the growth, photosynthesis and yield of chickpea under different levels of nitrogen. Urban Water Journal 7: 187-195.

Thapa U \& Maity TK (2003) Green and seed yield of fenugreek (Trigonella foenum graecum L.) as affected by nitrogen, phosphorus and cutting management. Journal of Interacademicia 7: 347-350.

Thompson G, Swain J, Kay M \& Forster C (2001) The treatment of pulp and paper mill effluent: a review. Bioresource Technology 77: 275-286.

Tuncturk R, Celen AE \& Tuncturk M (2011) The effects of nitrogen and sulphur fertilizers on the yield and quality of fenugreek (Trigonella foenum-graecum L.). Turkish Journal of Field Crops 16: 69-75.

Van der Hoek W, Hassan MU, Ensink JHJ, Feenstra S, RaschidSally L, Munir S, Aslam R, Ali N, Hussain R \& Matsuno Y (2002) Urban wastewater: A valuable resource for agriculture. A case study from Haroonabad, Pakistan. Research Report 63, International Water Management Institute, Colombo, Sri Lanka.

Walkley AJ \& Black IA (1934) Estimation of soil organic carbon by the carbonic acid titration method. Soil Science 37: 29-38.

Wang WG, Li R, Liu B, Li L, Wang SH \& Chen F (2011) Effects of low nitrogen and drought stress on proline biosynthesis of Jatropha curcas seedling. Acta Physiologia Plantarum 33: 1591-1595.

Williams CH, Singh RN \& Vlamis AH (1967) Metals in sludge-amended soils: A nine-year study. Soil Science 2: 86-93.

WHO (1989) Health guidelines for the use of wastewater in agriculture and aquaculture. World Health Organization Technical Report Series 778, Geneva.

Xiao K, Zhang RX \& Qian WP (1998) The physiological mechanism of senescence and photosynthetic function decline of flag leaf in wheat regulated by nitrogen nutrition. Plant Nutrition and Fertilizer Science 4: 371378 [in Chinese].

Xu J, Zhang J, Xie H, Li C, Bao N, Zhang C \& Shi Q (2010) Physiological responses of Phragmites australis to wastewater with different chemical oxygen demands. Ecological Engineering 36: 1341-1347.

Yordanova R, Christov K \& Popora LP (2003) Antioxidative enzymes in Barley plants subjected to soil flooding. Environmental and Experimental Botany 51: 93-101.

Yoshida I \& Ishii T (1993) Studies on the reuse of purified wastewater: Effects of purified wastewater on soil. Bulletin of the Faculty of Agriculture, Tottori University.

Zhang F, Wang Z \& Dong J (2007) Effect of heavy metal stress on antioxidative enzymes and lipid peroxidation 
in leaves and roots of two mangrove plant seedlings (Kandelia candel and Bruguira gymnorrhiza). Chemosphere 67: 44-50.

Zhang J \& Kirkham MB (1996) Antioxidation responses to drought in sunflower and sorghum seedling. New Phytologist 132: 361-373.

Zhang LX, Li SX, Zhang H \& Liang ZS (2007) Nitrogen rates and water stress effects on production, lipid peroxidation and antioxidative enzyme activities in two maize (Zea mays L.) genotypes. Journal of Agronomy and Crop Science 193: 387-397.

Zhao C \& Liu Q (2009) Growth and physiological responses of Picea asperata seedlings to elevated temperature and to nitrogen fertilization. Acta Physiologia Plantarum 31: 163-173.

Zhao Y (2011) Cadmium accumulation and antioxidative defenses in leaves of Triticum aestivum L. and Zea mays L. African Journal of Biotechnology 10: 2936-2943.

Zyadah MA \& Abdul-Bakky TC (2000) Toxicity and bioaccumulation of copper, zinc and cadmium in some aquatic organisms. Bulletin of Environmental Contamination and Toxicology 64: 740-747. 